\title{
Afet ve Kaza Riskinin Yüksek Olduğu Sanayi ve Maden Kuruluşlarında Çalışanların İş Sağlığı ve Güvenliği Kapsamında Güvenlik İklim Algısı ve İlk Yardım Bilgi Düzeylerinin Belirlenmesi Üzerine Bir Çalışma: Gümüşhane İli Örneği
}

\author{
A Study on Determination of Safety, Climate Perception and First Aid \\ Knowledge Levels in the Scope of Occupational Health and Safety of \\ Employees in Industrial and Mining Organizations where Disaster and \\ Accident Risk is High: The Case of Gümüşhane
}

Öz

Birçok insanın çalıştığ maden ve sanayi kuruluşlarında afetlere dönüşebilecek kazaların önüne geçmenin en etkili yolu eğitimlerden geçer. Bu çalışmada, Gümüşhane ili sanayi ve maden kuruluşlarında çalışanların kaza ve afetlere karşı güvenlik iklimi algıları ((iletişim, kadercilik, güvenlik yönetimi, bireysel sorumluluk, güvenlik standartları ve hedefler, kişisel katıllm, yönetim bağhlliğı) ve ilk yardım bilgi düzeyleri belirlemesi amaçlanmıştır. Katılimcılarını iletişim, güvenlik standartları ve hedefler ve güvenlik yönetimi algılar ile ilk yardım bilgi seviyeleri ; eğitim durumu yüksek olanlarda, geliri ve mesleki konumu yüksek olanlarda, İSG ve ilk yardım eğitimi alanların diğerlerine göre anlaml ve yüksek olduğu belirlenirken, kadercilik algılarının; bekar ve eğitim seviyesi az olanlarda, aylik geliri ile mesleki konum seviyesi düşük olanlarda, büyük işletmelerde çalışanlarda ayrıca ISSG ve İlk yardım eğitimi almayan ve iş kazası geçirenlerde yüksek ve istatistiksel olarak anlaml farklı olduğu belirlendi. Kişisel katılım algılarının kadınların erkekler göre, yönetim bağglllı̆̆ algılarının aylık geliri yüksek olanların düşük olanlara, bireysel sorumluluk algısı ise ; sanayi çalışanları, iş kazası geçirenlerde, ISG eğitimi almayanlarn diğerlerine göre daha yüksek ve anlaml farklllk gösterdiği gözlendi. Bu sonuçlar neticesinde çalışanların iş sağhlı̆̆ güvenliği ve ilk yardım eğitimlerinin tatbikatlarla pekiştirerek almaları onlara güvenli bir iş yeri sağlanmast için elzem olduğu belirlenmiştir.

\section{Abstract}

The most effective way to prevent accidents that can turn into disasters in mining and industrial establishments where many people work is through training. In this study, it was aimed to determine the safety climate perceptions ((communication, fatalism, safety management, individual responsibility, safety standards and targets, personal participation, management commitment) and first aid knowledge levels of the workers in industrial and mining establishments in Gümüşhane province. safety standards and targets and perceptions of safety management and first aid knowledge levels; those with high education, high income and professional position, OHS and first aid training are determined to be meaningful and higher than others, while fatalism perceptions; It was determined that there was a high and statistically significant difference among those who had a low monthly income and occupational position, employees in large enterprises, did not receive OHS and First Aid training, and had an occupational accident. The perception of individual responsibility for those with low levels; It was observed that industrial workers, those who had an occupational accident and those who did not receive OHS training, showed higher and significant differences compared to others. As a result of these results, it has been determined that it is essential for employees to receive occupational health, safety and first aid trainings by reinforcing them with exercises to provide them a safe workplace.

\begin{abstract}
Ali Said Yer
Öğretim Görevlisi, Erzurum Üniversitesi Horasan MYO

alisaidberad@hotmail.com

Orcid: 0000-0002-7468-8026

\section{Sevil Cengiz}

Dr. Öğretim Üyesi, Gümüşhane

Üniversitesi, SBF

sevil_cengiz@yahoo.com,

Orcid: 0000-0002-3562-1793

Article Type / Makale Türü

Research Article / Araştırma Makalesi

Anahtar Kelimeler

Afet Yönetimi, İş Sağllğı ve Güvenliği, İs Kazaları, İlk Yardım, Güvenlik İklimi

Keywords

Disaster Management, Occupational Health and Safety, Occupational Accidents, First-Aid, Security Climate
\end{abstract}

Bilgilendirme: Çalışma yüksek lisans tezinden üretilmiştir.

Submitted: $\quad 22$ / 12 / 2020

Accepted: $\quad 23 / 02 / 2021$ 


\section{Giriș}

Afetler ve kazalar insanlık ve insanlığın sahip olduğu tüm değerleri tehdit eden en büyük unsurlardır. Bu unsurlar, insanların uzun sürede sahip olabildiği/olabileceği ekonomik, sosyal, teknolojik ve kültürel düzeyi bir anda yeryüzünden silebilecek güçtedir (Martin, 2007). Tüm dünyada afet ve kazalarla mücadele edilebileceği kabul edilip bunların önüne geçebilmek için ulusal ve uluslararası düzeyde pek çok araştırmalar toplantılar ve planlamalar yapılmıştır. İnsanlık bu mücadelede kısmen başarılı olsa da, kat etmesi gereken uzun bir yola sahiptir. Ülkemizde ise doğal afetler karşısında birçok tedbirler alınmaya çalışılırken, son yıllardaki hızlı kentleşme ve sanayileşme beraberinde insan kaynaklı afet ve kazaların sayısında da ciddi bir artışa sebebiyet vermiştir.

Afet yönetimi, afet öncesini, afet anını ve sonrasını kapsayan bir yönetim şeklidir (hKaya, 2013). Afet yönetiminin en önemli hedefi, afet veya kazalar meydana gelmeden olası riskleri tespit etmeye çalışıp bunların tamamen ortadan kaldırılması veya en aza indirilmesidir. Aynı şekilde iş sağlı̆̆ 1 ve güvenliği (İSG) ile milyonlarca insanın istihdam edildiği iş sahalarında; tüm risk analizleri yapılarak, oluşturulan risk analiz raporlarının sonucuna göre gerekli tedbirler belirlenip, bu kapsamda çalışanlara ilkyardım, yangın söndürme, arama kurtarma ve tahliye eğitimleri uygulamalı tatbikatlarla verilerek afet veya kaza sonrası olabilecek olumsuz sonuçların azaltılması amaçlanır. Afet ve kazalar sonrası sanayi ve maden gibi kuruluşlarda çok yüksek boyutta kayıplar yaşanabilir. 2014 yılında Soma'da yaşanan maden faciası tüm ülkemizi etkilemiş ve ülke yönetiminin iş sahalarında meydana gelebilecek afet ve kazalara karşı alınacak tedbirleri bir daha gözden geçirmesini sağlamıştır (Yurdigül, 2014). Böylelikle sanayi ve maden gibi kuruluşlar başta olmak üzere İSG ve çalışanların ilk yardım eğitimi daha büyük bir önem kazanmıştır.

$\mathrm{Bu}$ çalışmada Gümüşhane ilinde bulunan sanayi ve maden kuruluşlarında çalışanlara anket yapılarak elde edilen bulgular sonucunda: iş sağlığı ve güvenliği ikliminin ölçümü ve ilk yardım bilgi düzeylerinin belirlenmesi hedeflenmiştir.

\section{Materyal ve Metod}

\section{1. Çalışmanın Önemi ve Amacı}

Ülkemiz edinmiş olduğu pek çok acı tecrübelerden sonra her türlü afet ve kazalara karşın riskleri ortadan kaldırmayı veya en aza indirmeyi amaçlayan yeni kanunlar düzenlemiş ve özellikle son yıllarda sürekli güncellenen yönetmeliklerle bunların uygulama safhasına girmiştir. Bu önemli tedbirlerden biride teknolojik veya insan kaynaklı afet ve kazaların önüne geçmeyi hedefleyen iş sağlığı ve güvenliği yasasıdır. Bu araştırma, sanayi ve maden kuruluşlarında çalışan personelin güvenlik iklimi algılarını ve ilk yardım bilgi düzeylerini ölçerek ülkemiz için büyük önem arz eden iş sağlığı ve güvenliği kavramının çalışan bireyler düzeyindeki konumuna 1şık tutabilecek küçük bir örnektir.

$\mathrm{Bu}$ araştırma türündeki çalışmanın amacı; sanayi ve maden kuruluşlarında çalışan insanların demografik bilgileri dikkate alınarak iş sağlığı ve güvenliği kapsamında ilk yardım bilgi düzeylerinin ve çalıştıkları iş ortamındaki güvenlik iklimi algılarının ölçülmesi, bu ölçümlerin birbirleri ile olan ilişkilerin belirlenmesidir.

\section{2. Çalışmada Kullanılan Yöntemler}

Gerekli litaratür çalışmaları yapılarak tarafımızca bir bir anket hazırlanmıştır. Anket formunun ilk bölümünde araştırmanın amacı ve kapsamı ile ilgili bilgilere, ikinci bölümde ise demografik özelliklere yer verilmiştir (13 soru). Sonraki bölümde ilk yardım bilgi düzeyi belirleme amaçlı doğru/yanlış/bilmiyorum şeklinde oluşturulmuş 25 soru ve son bölümde iş sağlı̆̆ ve güvenliği kapsamında çalışanların güvenlik iklimini ölçmeyi amaçlayan 5’li likert tipi ölçek kullanılan 49 soru bulunmaktadır. Ankete katılanlardan sorulan her bir ifadeye kendi görüşlerine uygun cevap vermeleri istenmiştir. Gümüşhane Şubesi çalışanları arasından tesadüfi olmayan örnekleme yöntemlerinden biri olan kolayda örnekleme metoduyla belirlenen bir örnek kitleye uygulanmıştır. Araştırma Gümüşhane ilindeki Gümüşhane Organize Sanayi Bölgesi, Koza Altın İşletmeleri A.Ş. Gümüşhane Şubesi, Gümüştaş Madencilik ve Ticaret A.Ş. Bu araştırma Gümüşhane ilinde bulunan 
Gümüşhane Organize Sanayi Bölgesi, Koza Altın İşletmeleri A.Ş. Gümüşhane Şubesi, Gümüştaş Madencilik ve Ticaret A.Ş. Gümüşhane Şubesi çalışanlarına yapılmıştır. Toplamda 340 çalışana ulaşılmıştır. Doldurulan anketlerin girilmesinde 43 anketin verilerinin eksik ve hatalı olduğu görülmüş ve analizden çıkarılmış, analize dahil edilen denek sayısı 297 olmuştur.

\subsection{Yöntemin Güvenirliği ve Geçerliliği}

Tarfımızdan oluşturulan kullandığımız ölçeğin geçerliliğini belirlemek için yüzey geçerliliği yöntemi uygulanmıştır. Güvenilirliğini belirlemek amacıyla yapılan uygulamada Cronbach's Alpha 0,92 bulunarak güvenilir kabul edilmiştir.

\subsection{Araştırmanın Kısıtlılıkları}

Zaman ve maliyet kısıtlarından dolayı araştırma evreni Türkiye genelini kapsayacak şekilde ele alınmamış, sadece Gümüşhane ilindeki Gümüşhane Organize Sanayi Bölgesi, Koza Altın İşletmeleri A.Ş. Gümüşhane Şubesi, Gümüştaş Madencilik ve Ticaret A.Ş. Gümüşhane Şubesi çalışanlarıyla sinırlandırılmıştır. Bu araştırmada tesadüfi olmayan örnekleme metotlarından biri olan kolayda örnekleme metodu kullanılmıştır.

\subsection{Araştırma Bulgularının Analizi}

Verilerin analizinde SPSS 17 paket programı kullanılmıştır. Anket formlarındaki demografik verilerin analizi için frekans, yüzde dağılımı, aritmetik ortalama gibi istatistiksel analizler yapılmış tablolar ve grafikler halinde gösterilmiştir. Bulguların normal dağılıma uyup uymadığını belirlemek için ise One-Sample Kolmogorov-Smirnov Testi uygulanmıştır. Buradaki (anlamlılık $p<0,05^{\prime}$ den olduğu (Tablo 1) normal dağılım göstermediği tespit edilip nonparametrik testler uygulanmıştır. Araştırmanın istatistiksel analizlerinde ; Kruskal-Wallis, Mann-Whitney U testi kullanılmıştır.

\section{Demografik Bulgular}

\subsection{Araştırmanın Evreni ve Örneklemi}

Anket Gümüşhane ilinde bulunan Gümüşhane Organize Sanayi Bölgesi, Koza Altın İşletmeleri A.Ş. Gümüşhane Şubesi, Gümüştaş Madencilik ve Ticaret A.Ş. Gümüşhane Şubesi çalışanlarından toplamda 340 çalışana ulaşılmıştır. Doldurulan anketlerin girilmesinde 43 anketin verilerinin eksik ve hatalı olduğu görülmüş ve analizden çıkarılmış, analize dahil edilen denek sayısı 297 olmuştur. Ankete Katılanların demografik değerleri Tablo 1 de verilmiştir.

Çalışmaya katılanların \% 72,1 2 i (214 kişi) ilk yardım eğitimi aldıklarını, eğitimi nereden aldıkları sorulduğunda öncelikli olarak iş yerleri olmak üzere farklı yerlerden (Tablo 2) aldıkları, “ílk Yardım eğitimi almak ister misiniz ?" sorusuna ise \% 75,1 ' (223 kişi) olumlu baktı̆̆ı belirlendi.

Tablo 1. Demografik Bulgular

\begin{tabular}{|c|c|c|c|c|c|}
\hline Cinsiyet & Sayx & $\%$ & Medeni durum & Sayi & $\%$ \\
\hline Kadin & 30 & 10.1 & Evli & 209 & 70.4 \\
\hline Erkek & 267 & 89.9 & B ekar & 88 & 29.6 \\
\hline Yas & Sayx & $\%$ & Calisma Yili & Sayx & $\%$ \\
\hline $18-25$ & 23 & 7.7 & $0-5$ y.1 & 68 & 22.9 \\
\hline $26-34$ & 135 & 45.5 & $6-10$ y11 & 124 & 41.8 \\
\hline $35-45$ & 88 & 29.6 & 11-15 y11 & 33 & 11.1 \\
\hline $46-55$ & 40 & 13.5 & $16-20$ yil & 30 & 10.1 \\
\hline \multirow[t]{2}{*}{56 ve uzeri } & 11 & 3.7 & 21-25 yil & 21 & 7.1 \\
\hline & & & 26 yil ve izeri & 21 & 7.1 \\
\hline Egitim & Sayı & $\%$ & Gelir Durumu & Sayi & $\%$ \\
\hline Ilkoku1 & 42 & 14.1 & Çok dușuk & 33 & 11.1 \\
\hline Ortaokul ve dengi & 53 & 17.8 & Duşuk & 71 & 23.9 \\
\hline Lise ve dengi & 116 & 39.1 & Orta & 179 & 60.3 \\
\hline \multirow{2}{*}{$\begin{array}{l}\text { Yüksekokul/ } \\
\text { Universite }\end{array}$} & 86 & 29.0 & Yuksek & 13 & 4.4 \\
\hline & & & Çok yüksek & 1 & 0.3 \\
\hline Konum & Sayr & $\%$ & Is Dalx & Sayi & $\%$ \\
\hline Iş̧̧̧i & 128 & 43.1 & Maden & 159 & 53.5 \\
\hline Teknisyen & 20 & 6.7 & Sanayi & 138 & 46.5 \\
\hline Uzman & 20 & 6.7 & & & \\
\hline Yönetici & 39 & 13.1 & & & \\
\hline Usta & 82 & 27.6 & & & \\
\hline Cirak & 8 & 2.7 & & & \\
\hline
\end{tabular}




\begin{tabular}{lcc} 
Tablo 2. Çalışanların İlk yardım Eğitimini Nereden Aldıla \\
\hline & Kişi Sayısı & Yüzde \\
Askerlikte & 45 & 15,2 \\
Ehliyet kursunda & 39 & 13,1 \\
İlk yardım merkezleri & 43 & 14,5 \\
Kendi kurumumda & 87 & 29,3 \\
Toplam & 214 & 72,1
\end{tabular}

Çalışanların \%39,1'i (118 kişi) iş yerinde kaza geçirdiklerini belirtirken; kazanın türü sorulduğunda verilen cevaplar Tablo 3 de verilmiştir.

Tablo 3. Çalışanların Geçirdiği İş Kazası Türü Dağılımı

\begin{tabular}{lcc}
\hline Isı kaynaklı yanık & Kişi Sayısı & Yuzde \\
Kesik & 15 & 12,9 \\
Soluk borusunda tıkanma & 35 & 30,2 \\
Bayılma veya bilinç kaybı & 5 & 4,3 \\
Göze yabancı cisim kaçması & 5 & 4,3 \\
Buruna yabancı cisim kaçması & 10 & 8,6 \\
Kirık, çıkł, burkulma ve ezilme & 2 & 1,7 \\
Zehirlenme & 25 & 21,6 \\
Elektrik çarpması & 1 & 0,9 \\
Uzuv kopması & 9 & 7,8 \\
Sert cisim saplanması. & 1 & 0.9 \\
Toplam & 8 & 6,9 \\
\hline
\end{tabular}

Çalışanların \%57,6 sı (171kişi) İş Sağlığı ve Güvenliği Eğitimini kurumlarında aldıklarını ve \%81,8 (243 kişi) eğitim verilir ya da tekrarlanırsa eğitim alabileceklerini belirtiler.

\section{3. Çalışanların İlk Yardım Bilgi Düzeyleri Üzerine Tanımlayıcı Analizler}

Çalışanların İlk Yardım Bilgi Düzeyleri belirlemek için Bilgi Sorularına verdikleri doğru cevap oranları Toplu Bulguları Tablo 4' de belirtilmiştir.

Sorulara verilen cevaplar incelendiğinde en fazla doğru cevap verilen soruların , "İlkyardım olay yerinde tıbbi araç ve gereç olmasa da mevcut ilaçlarla yapılan ilaçsız müdahaledir" $(\% 95,6)$, "Gaz zehirlenmelerinde kazazedenin hemen ortamdan uzaklaştırılıp açık havaya çıartılması gerekir" $(\% 94,3)$ gerekmektedir ve "Illkyardımın önemli amaçlarından biri hayati tehlikeyi ortadan kaldırmaktır" $(\% 91,2)$ soruları olduğu belirlenmiştir. 


\section{Tablo 4. İlk Yardım Bilgi Düzeyleri Toplu Bulguları}

\section{İLK YARDIM BİLGİ DÜZEYİ ANKET FORMU Her soru için size en uygun gelen ifadeyi ișaretleyiniz.}

Doğru

Yüzdesi

1- İlk yardım olay yerinde, tibbi araç ve gereç olmasada mevcut imkanlarla yapılan ilaçsiz müdahaledir.

2- Göze yabancı bir cisim batması durumunda cisim derhal çıkarılmalıdır.

Hasta veya yaralının en yakın sağlık kuruluşuna sevkini sağlamak amacıyla 155 telefon numarasi aranir.

4- Kalp durmasına ilk 5 dakikada müdahale edilmelidir.

5- Kanamayı durdurmak için kanamalı bölgenin üzeri temiz bir bezle kapatılarak yaraya bask1 uygulanir.

6- Burun kanamasında baş arkaya eğilerek 5 dakika burun kanatlarına baskı uygulanır.

7- Bayılmış olan bir kiși ilk olarak tokatlanarak ayıltılmaya çalıș1ır.

8. Karın bölgesine yabancı bir cisim saplandığında hemen yabancı cisim bulunduğu bölgeden çıkarılmalı ve kanayan bölgeye basınç yapılmalıdır.

9. Kaza sonucu oluşan yanmalarda yanık bölge üzerine hemen ilaç ya da yanık merhemi gibi maddeler sürülmelidir.

Kanamayı durdurmak için ilk olarak kanayan bölge kolonya veya tentürdiyot ile

10- temizlenmelidir.

11- Yaralanma sonucu dişarı çıkan organlar tekrar yerleştirilmeye çalışılmamalıdır, üzerleri temiz bir bez ile örtülmelidir.

12- Elektrik çarpması sırasında elektrik çarpan kişi derhal elle tutup cekilir.

13- Bayılma durumunda bayılan kişi surt üstü yatırılıp, ayaklar hafifçe yükseltilir.

14- Bilinci kapalı olan bir kişiye kendisine gelmesi için su içirilmelidir.

15- Boğazına yabancı cisim kaçan bir kişiye en uygun ilk yardım geçmesini beklemektir.

16- İlk yardımın öncelikli amaçlarından birisi hayati tehlikeyi ortadan kaldırmaktır. Asit veya petrol ürünü maddeleri (gaz yağı, benzin,....) yanlıșl1kla içen bir kiși

17- derhal kusturulmalidir.

18- Gaz zehirlenmelerinde kazazedenin hemen ortamdan uzaklaştırllıp, açık havaya ç1kartılması gerekir.

19- Uzuv kopmalarında kopan parça doğrudan buz içerisine konulmalıdır.

20- Bir kaza sonucu kiși bayıldıysa, sırt üstï yatırılarak ayakları $30 \mathrm{~cm}$ kaldırılır.

21- Yaralının ilk değerlendirilmesinde ilk önce kanaması olup olmadığına bakı1ır.

22- İlk yardım esnasında kırıldığı anlaşılan kısımlar düzeltilmeye çalışılmalıdır.

23- İlk yardımın önceliği ağrıyı azaltmaktır.

Kaza sonucu parmak kopması görülen kișinin kopan parmağı doğrudan buz

24- dolu bir kap içeresine konularak kişiyle beraber derhal bir sağlik kuruluşuna sevki sağlanır.

25- Kaynar suyla olușan yanmalarda yanan kısım soğuk, temiz ve akan suya tutulur. 


\section{4. Çalışanların İş Sağlığı ve Güvenliği Kapsamında Güvenlik İklimi Düzeyleri Üzerine Tanımlayıcı Analizler}

\section{Tablo 5. Güvenlik İklimi Ölçeğinde Bulunan Soruların Toplu Bulguları}

\begin{tabular}{|c|c|c|c|c|c|c|c|}
\hline & $\begin{array}{l}\text { Aşağıda belirtilen iş sağlı̆̆ı ve güvenliği anket formunda yer } \\
\text { alan her soru 1'den 5'e kadar derecelendirilmiştir. } \\
\text { (1)Kesinlikle Katılmıyorum, (2)Katılmıyorum, (3)Kararsızım, } \\
\text { (4)Katılıyorum, (5)Tamamen katılıyorum şeklindedir. }\end{array}$ & 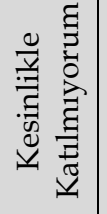 & 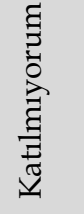 & 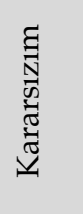 & 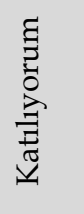 & 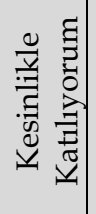 & 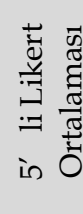 \\
\hline 1- & $\begin{array}{l}\text { İ̧sletmemde iş sağlığı ve güvenliği konuları ile ilgili etkili bir } \\
\text { iletişim vardır. }\end{array}$ & 10,8 & 16,5 & 17,2 & 31,0 & 24,6 & 3,42 \\
\hline 2- & $\begin{array}{l}\text { İş sağlı̆̆ı ve güvenliği ile ilgili yapılması gereken işler her } \\
\text { zaman yerine getirilir. }\end{array}$ & 1.7 & 5.4 & 17,2 & 43.4 & 32.3 & 3,99 \\
\hline 3- & $\begin{array}{l}\text { İş sağlığı ve güvenliği konusunda özenli çalışmam, başarımı } \\
\text { olumlu yönde etkiler. }\end{array}$ & 1.3 & 1.0 & 6.7 & 34.7 & 56.2 & 4,43 \\
\hline 4- & İşletmede işlerin en kısa yoldan yapılması önemlidir. & 21.2 & 20.9 & 13.1 & 24.2 & 20.5 & 3,02 \\
\hline 5- & İşletmede sadece birkaç kişi iş sağlığı ve güvenliği ile ilgilenir. & 30.6 & 24.9 & 12.5 & 19.2 & 12.8 & 2,58 \\
\hline 6- & $\begin{array}{l}\text { Çalışma yöntemlerindeki değişiklikler ve bunların iş sağlığı ve } \\
\text { güvenliği üzerindeki etkisi çalışanlara iletilir. }\end{array}$ & 3.0 & 7.4 & 15.5 & 44.1 & 30.0 & 3,90 \\
\hline 7- & $\begin{array}{l}\text { Yönetim, iş sağlı̆̆ı ve güvenliği ile ilgili sorunların ortaya } \\
\text { çıkması durumunda kararlı davranışlar sergiler. }\end{array}$ & 2.7 & 7.4 & 14.5 & 41.8 & 33.7 & 3,96 \\
\hline 8- & İşimde risk almaktan kaçınamam. & 2.7 & 7.4 & 14.5 & 41.8 & 33.7 & 2,65 \\
\hline 9- & $\begin{array}{l}\text { İşletmede iş sağlı̆̆1 ve güvenliği konusunda sürekli iyileştirme } \\
\text { süreci mevcuttur. }\end{array}$ & 4.7 & 9.1 & 18.5 & 39.1 & 28.6 & 3,77 \\
\hline $10-$ & Kazalar işin bir parçası olarak hoş görülür. & 44.4 & 25.9 & 11.1 & 10.8 & 7.7 & 2,11 \\
\hline 11- & $\begin{array}{l}\text { Çalışma arkadaşlarımın güvenliğini gözetirim / güvenliğine } \\
\text { dikkat ederim. }\end{array}$ & 3.0 & 4.0 & 5.1 & 34.7 & 53.2 & 4,30 \\
\hline $12-$ & Toplantılar iş sağlığı ve güvenliği konularını da içerir. & 2.4 & 5.1 & 14.5 & 33.7 & 44.4 & 4,12 \\
\hline 13- & $\begin{array}{l}\text { İş sağlı̆̆ ve güvenliği ile ilgili önemli konularda yönetimi } \\
\text { bilgilendiririm. }\end{array}$ & 3.0 & 3.4 & 13.1 & 40.4 & 40.1 & 4,11 \\
\hline 14- & İşletmemizde iş sağlığı ve güvenliği yüksek öncelik taşır. & 6.7 & 7.4 & 16.8 & 29.3 & 39.7 & 3,87 \\
\hline 15- & $\begin{array}{l}\text { Ne yaparsam yapayım kazaların gerçekleşmesini } \\
\text { engelleyemem. }\end{array}$ & 39.4 & 32.0 & 7.4 & 11.8 & 9.4 & 2,19 \\
\hline 16- & Güvenlik toplantılarının sonuçları hakkında bilgilendiriliriz. & 4.4 & 9.8 & 17.2 & 35.0 & 33.7 & 3,83 \\
\hline 17- & $\begin{array}{l}\text { İşletmede iş sağlığı ve güvenliği konusunda geliştirilmiş başarı } \\
\text { standartları mevcuttur. }\end{array}$ & 10.4 & 15.2 & 20.2 & 28.3 & 25.9 & 3,44 \\
\hline 18- & $\begin{array}{l}\text { Birim yöneticileri etkin bir şekilde/faal olarak iş sağlığı ve } \\
\text { güvenliğine destek olurlar. }\end{array}$ & 2.7 & 7.1 & 14.1 & 41.8 & 34.3 & 3,97 \\
\hline 19- & $\begin{array}{l}\text { İşletmede iş sağllğ̆ ve güvenliği konusunda verilen eğitimler } \\
\text { yeterli değildir. }\end{array}$ & 24.9 & 25.9 & 20.5 & 21.2 & 7.4 & 2,60 \\
\hline $20-$ & $\begin{array}{l}\text { İsyerinde oluşabilecek riskler ve bunların yaratacağı sonuçlar } \\
\text { eğitimlerde anlatılır. }\end{array}$ & 3.4 & 11.4 & 13.1 & 38.4 & 33.7 & 3,87 \\
\hline 21- & $\begin{array}{l}\text { İşyerinde yönetim, iş sağllğ̆ ve güvenliği ile ilgili konuları } \\
\text { görmemezlikten gelmektedir. }\end{array}$ & 36.0 & 29.3 & 16.5 & 11.8 & 6.4 & 2,23 \\
\hline $22-$ & $\begin{array}{l}\text { Yönetim çalışanların iş sağlığı ve güvenliği konusundaki } \\
\text { endişelerini dinler. }\end{array}$ & 6.1 & 8.1 & 10.8 & 39.4 & 35.7 & 3,90 \\
\hline 23- & İşimi yaparken, güvenli şekilde çalışmam şarttır. & 0.7 & 3.0 & 4.7 & 30.6 & 60.9 & 4,48 \\
\hline 24- & $\begin{array}{l}\text { Bana güvenli şekilde çalışmam için neler yapmam gerektiği } \\
\text { gösterilmiştir. }\end{array}$ & 1.3 & 3.0 & 9.1 & 40.1 & 46.5 & 4,27 \\
\hline $25-$ & İşletmede güvensiz davranışlar hoş görülür/tolere edilir. & 51.2 & 26.3 & 6.4 & 12.5 & 3.7 & 1,91 \\
\hline 26- & Yönetim, iş kazalarını önlemek için yeterince çaba gösterir. & 3.0 & 6.1 & 18.9 & 38.7 & 33.3 & 3,93 \\
\hline 27- & $\begin{array}{l}\text { Çalışanlar her zaman işletmenin iş sağlığı ve güvenliği } \\
\text { konusunda yüksek düzeye gelmesini amaçlarlar. }\end{array}$ & 1.3 & 3.0 & 11.8 & 40.7 & 43.1 & 4,21 \\
\hline 28- & $\begin{array}{l}\text { Amirim/ yöneticim, iş sağlı̆̆ı ve güvenliği ile ilgili mevcut } \\
\text { konular ve sorunlar hakkında bana her zaman bilgi vermez. }\end{array}$ & 26.6 & 24.9 & 10.8 & 22.2 & 15.5 & 2,75 \\
\hline 29- & $\begin{array}{l}\text { Birim yöneticileri sadece kazalardan sonra iş sağlı̆̆ı ve } \\
\text { güvenliği ile ilgilenirler. }\end{array}$ & 34.3 & 32.7 & 16.2 & 12.5 & 4.4 & 2,19 \\
\hline $30-$ & Her zaman kazaları ve olayları rapor ederiz. & 10.1 & 13.8 & 13.8 & 28.3 & 34.0 & 3,62 \\
\hline $31-$ & $\begin{array}{l}\text { İşletmede yaşanan kazalardan ders alınarak iş sağlığı ve } \\
\text { güvenliği konusunda ilerleme/gelişme kaydedilir. }\end{array}$ & 3.0 & 8.1 & 11.8 & 40.4 & 36.7 & 3,99 \\
\hline
\end{tabular}




\begin{tabular}{|c|c|c|c|c|c|c|c|}
\hline 32- & $\begin{array}{l}\text { Eğer iş sağlığı ve güvenliği konusunda sürekli endişelenirsem, } \\
\text { bu durum işimi yapmamı engeller. }\end{array}$ & 9.4 & 10.8 & 6.7 & 30.3 & 42.8 & 3,86 \\
\hline 33- & $\begin{array}{l}\text { Yöneticiler ve amirler iş sağlığı ve güvenliğ̆i kurallarına } \\
\text { uyulmadığı zaman endişelerini dile getirirler. }\end{array}$ & 3.0 & 10.8 & 16.5 & 40.1 & 29.6 & 3,95 \\
\hline 34- & $\begin{array}{l}\text { Tüm çalışanlar iş sağlığı ve güvenliği konusunda faaldir/etkin } \\
\text { rol oynar. }\end{array}$ & 4.7 & 7.4 & 16.2 & 33.3 & 38.4 & 3,93 \\
\hline 35- & $\begin{array}{l}\text { Bizi meşgul eden başka önceliklerimiz olmadığı zaman, iş } \\
\text { sağlığı ve güvenliğine önem veririz. }\end{array}$ & 16.5 & 16.8 & 12.5 & 27.6 & 26.6 & 3,30 \\
\hline 36- & $\begin{array}{l}\text { Güvensiz davranışlar sergileyen çalışanlar için yönetim } \\
\text { tarafından gerekli disiplin önlemleri alınır. }\end{array}$ & 7.7 & 10.4 & 14.5 & 36.7 & 30.6 & 3,72 \\
\hline $37-$ & $\begin{array}{l}\text { Yönetim, güvensiz uygulamalar konusunda uyarıldığında, } \\
\text { düzeltici önlemler her zaman alınır. }\end{array}$ & 6.7 & 8.4 & 13.5 & 39.1 & 32.3 & 3,81 \\
\hline 38- & $\begin{array}{l}\text { Çalıştığım bölümü/departmanı ilgilendiren diğer bölümlerdeki } \\
\text { işlerle ilgili olarak iş sağlığı ve güvenliği konularında iletişim } \\
\text { sağlanır. }\end{array}$ & 5.7 & 8.8 & 17.5 & 31.6 & 36.4 & 3,84 \\
\hline 39- & $\begin{array}{l}\text { İşyerinde, amirler/yöneticiler iş sağlı̆̆ım ve güvenliğim } \\
\text { konusunda ilgilidirler. }\end{array}$ & 3.4 & 7.7 & 16.2 & 36.4 & 36.4 & 3,94 \\
\hline 40- & $\begin{array}{l}\text { İşs sağllğı ve güvenliği hedefleri çalışanlar tarafından } \\
\text { tanımlanır. }\end{array}$ & 13.1 & 16.8 & 21.9 & 27.6 & 20.5 & 3,25 \\
\hline 41- & $\begin{array}{l}\text { İşyerimde iş sağlığı ve güvenliğini geliştirmek için hiçbir şey } \\
\text { yapamam. }\end{array}$ & 17.2 & 14.1 & 15.5 & 30.6 & 22.6 & 2,12 \\
\hline 42- & $\begin{array}{l}\text { İşyerimde yönetim işs sağllğı ve güvenliği problemlerini } \\
\text { düzeltmekte hızlı davranır. }\end{array}$ & 40.1 & 32.0 & 10.4 & 10.1 & 7.4 & 3,27 \\
\hline 43- & İşletmede iş sağlığı ve güvenliğ̈i eğitimi yüksek öncelik taşır. & 9.4 & 11.4 & 13.5 & 34.7 & 31.0 & 3,66 \\
\hline $44-$ & $\begin{array}{l}\text { İss sağllğı ve güvenliği konusunda ben ve iş arkadaşlarım } \\
\text { birbirimize yardım ederiz. }\end{array}$ & 5.1 & 4.7 & 10.1 & 35.0 & 45.1 & 4,10 \\
\hline 45- & Yönetim kazalar gerçekleştikten sonra harekete geçer. & 30.6 & 22.6 & 10.8 & 22.2 & 13.8 & 2,65 \\
\hline $46-$ & $\begin{array}{l}\text { Yönetim, iş sağlığı ve güvenliği konularında öncülük/liderlik } \\
\text { eder. }\end{array}$ & 2.7 & 7.4 & 13.8 & 42.1 & 34.0 & 3,97 \\
\hline $47-$ & $\begin{array}{l}\text { İşletmenin iş sağlığı ve güvenliği konusundaki başarısı } \\
\text { gelişmektedir/artmaktadır. }\end{array}$ & 1.7 & 6.7 & 9.8 & 40.4 & 41.4 & 4,13 \\
\hline 48- & $\begin{array}{l}\text { Amirim/yöneticim iş sağllı̆ı ve güvenliği ile ilgili bilgileri her } \\
\text { zaman benimle paylaşır. }\end{array}$ & 2.4 & 5.7 & 13.8 & 37.4 & 40.7 & 4,08 \\
\hline 49- & $\begin{array}{l}\text { İşs sağllğı ve güvenliği konusundaki hedefler, yönetim } \\
\text { tarafından düzenli olarak gözden geçirilir. }\end{array}$ & 2.4 & 4.0 & 11.4 & 37.7 & 44.4 & 4,17 \\
\hline
\end{tabular}

\section{Demografik Özellikler ile Güvenlik İklimi Algısı, Alt Boyutları ve İlk Yardım Bilgi Düzeyleri Arası İlişkiler Analizi}

Demografik Özellikler ile Güvenlik İklimi Algısı, 7 Alt Boyutları (iletişim, Kadercilik, Güvenlik Yönetimi, Bireysel Sorumluluk, Güvenlik Standartları ve Hedefler, Kişisel Katılım, Yönetim Bağlılığı) ve İlk Yardım Bilgi Düzeyleri aralarında anlamlı farklılık olup olmadığı ile ilgili analizler yapıldığında;

Çalışanlar cinsiyetleri arasında "kişisel katılım" boyutu arasında Mann-Whitney U -Test analizine göre anlamlı bir farklılık ( $p=0,020)$ gözlemlenmiştir (Tablo 6).

Tablo 6. Cinsiyet ile güvenlik iklimi alt İstatistikleri

\begin{tabular}{|c|c|c|c|c|c|c|c|c|c|}
\hline & $\begin{array}{c}\text { Güvenlik } \\
\text { Iklimi } \\
\text { Ortalama }\end{array}$ & İletişim & Kadercilik & $\begin{array}{c}\text { Güvenlik } \\
\text { Yönetimi }\end{array}$ & $\begin{array}{c}\text { Bireysel } \\
\text { Sorumluluk }\end{array}$ & $\begin{array}{c}\text { Güvenlik } \\
\text { Standartları } \\
\text { Ve Hedefler }\end{array}$ & $\begin{array}{c}\text { Kișisel } \\
\text { Kathlım }\end{array}$ & $\begin{array}{c}\text { Yönetim } \\
\text { Bağllığı }\end{array}$ & $\begin{array}{c}\text { Ilk Yardım } \\
\text { Bilgi Puanı }\end{array}$ \\
\hline $\mathrm{Z}$ &,- 879 &,- 748 & $-1,673$ &,- 521 &,- 934 &,- 567 & $-2,330$ & $-1,480$ & $-1,285$ \\
\hline $\mathrm{p}$ &, 379 &, 455 &, 094 &, 602 &, 350 &, 570 & $\mathbf{, 0 2 0}$ &, 139 &, 199 \\
\hline
\end{tabular}

Çalışanların eğitim durumları ile "iletişim", "kadercilik", "güvenlik standartları ve hedefler" boyutları ve "ilk yardım bilgi puanı" ( $p=0,049, p=0,000, p=0,003, p=0,000)$. arasında Kruskal Wallis Test analizine göre anlamlı bir farklılık gözlemlenmiştir (Tablo 7). 
Tablo 7.Ĕgitim Durumu Kruskal Wallis Test İstatistikleri

\begin{tabular}{|l|c|c|c|c|c|c|c|c|c|}
\hline & $\begin{array}{c}\text { Güvenlik } \\
\text { İklimi } \\
\text { Ortalama }\end{array}$ & İletişim & Kadercilik & $\begin{array}{c}\text { Güvenlik } \\
\text { Yönetimi }\end{array}$ & $\begin{array}{c}\text { Güvenlik } \\
\text { Sorreysel } \\
\text { Standartları } \\
\text { Ve } \\
\text { Hedefler }\end{array}$ & $\begin{array}{c}\text { Kişisel } \\
\text { Katilım }\end{array}$ & $\begin{array}{c}\text { Yönetim } \\
\text { Bağlliğı }\end{array}$ & $\begin{array}{c}\text { Illk Yardım } \\
\text { Bilgi Puamı }\end{array}$ \\
\hline Chi-Square & 3,455 & 7,877 & 21,367 & 4,760 & 2,382 & 14,165 &, 462 & 4,337 & 51,797 \\
\hline df & 3 & 3 & 3 & 3 & 3 & 3 & 3 & 3 & 3 \\
\hline$p$ &, 327 &, 049 &, 000 &, 190 &, 497 &, 003 &, 927 &, 227 &, 000 \\
\hline
\end{tabular}

Çalışanların medeni duruma göre; iletişim", "kadercilik”, "güvenlik yönetimi”, "Güvenlik Standartları ve Hedefler" için ( $p=0,011, p=0,002, p=0,009, p=0,022, p=0,005)$ Mann-Whitney U -Test analizine göre anlamlı bir farklılık olduğu belirlendi.

Çalışanların yaşlarına göre güvenlik iklimi algısı, güvenlik iklimi alt boyutları ve ilk yardım bilgi düzeyleri arasında "Kadercilik" ve "Güvenlik Standartları ve Hedefler alt boyutları arasında anlamlı $(\mathrm{p}=0,053, \mathrm{p}=0,023)$ Kruskal Wallis Test analizine göre anlamlı bir farklılık gözlemlenmiştir.

Çalışanların aylık gelirleri ile Güvenlik İklimi Algısı" ve alt boyutları olan "İletişim”, "Kadercilik", "Güvenlik Yönetimi”, "Güvenlik Standartları Ve Hedefler","Yönetim Bağlllı̆̆ı" arasında Kruskal Wallis Test analizine göre anlamlı bir farklılık (tümü için p=0,000) gözlemlenmiştir. Çalışanların iş dalları ile "iletişim", "kadercilik”, "bireysel sorumluluk”, "güvenlik standartları ve hedefler", "kişisel katılım", "yönetim bağlılı̆̆ı" boyutları ve "ilk yardım bilgi puanı" arasında Kruskal Wallis Test analizine göre anlamlı bir $(p=0,013, p=0,000, p=0,000, p=0,000, p=0,000$, $\mathrm{p}=0,022, \mathrm{p}=0,000$ ) farklılık gözlemlenmiştir .

Araştırmamızda madenler büyük işletmeler iken sanayi birimleri küçük işletmelerden oluşmaktadır. Çalışanlar çalıştıkları işletmenin büyüklüğüne göre "İletişim”, "Kadercilik”, "bireysel sorumluluk", "Güvenlik Standartları ve Hedefler" ve " "ilk yardım bilgi puanı" arasında MannWhitney U-Test analizine göre anlamlı bir ( $p=0,010, p=0,004, p=0,000, p=0,001, p=0,000, p=0,000)$ farklılık gözlemlenmiştir. Çalışanlar mesleklerindeki konumlarına göre; Çalışanların mesleklerindeki konumları ile "güvenlik iklimi algısı" ve alt boyutları olan "iletişim", "kadercilik", "güvenlik yönetimi", "güvenlik standartları ve hedefler" ve "ilk yardım bilgi puanı" arasında Kruskal Wallis Test analizine göre anlamlı $(p=0,010, p=0,000, p=0,000, p=0,002, p=0,000, p=0,000)$. bir farklılık gözlemlenmiştir.

Çalışanlar ilk yardım eğitimi alıp almamaları ile güvenlik iklimi algısı, güvenlik iklimi alt boyutları ve ilk yardım bilgi düzeyleri arasında, "İletişim", "Kadercilik", "Güvenlik Yönetimi”, "Güvenlik Standartları Ve Hedefler" ve "İlk Yardım Bilgi Puanı" arasında Mann-Whitney U -Test analizine göre anlamlı $(p=0,044, p=0,000, p=0,002, p=0,001, p=0,000)$ bir farklılık gözlemlenmiştir. Çalışanların ilk yardım eğitimi alma istekleri ile "İletişim", "Kadercilik" ve "Illk Yardım Bilgi Puanı" arasında Mann-Whitney U -Test analizine göre anlamlı $(p=0,009, p=0,053, p=0,031)$ bir farklılık gözlemlenmiştir.

Çalışanların ilk yardım eğitimi alma istekleri ile "Kadercilik", "Bireysel Sorumluluk", "Güvenlik Standartları ve Hedefler" ve "İlk Yardım Bilgi Puanı" arasında Mann-Whitney U -Test analizine göre anlamlı $(p=0,001, p=0,004, p=0,000, p=0,013)$ bir farklılık gözlemlenmiştir.

Çalışanların iş sağlığı ve güvenliği eğitimi alıp almama durumları ile "İletişim", "Kadercilik", "Güvenlik Yönetimi”, “Bireysel Sorumluluk”, "Güvenlik Standartları ve Hedefler”, ve "İlk Yardım Bilgi Puanı" arasında Mann-Whitney U -Test analizine göre anlamlı $(p=0,019, p=0,000, p=0,047$, $\mathrm{p}=0,026, \mathrm{p}=0,000, \mathrm{p}=0,000)$ bir farklılık gözlemlenmiştir. Araştırmanın temel değişkenleri olan çalışanların "güvenlik iklimi algı düzeyi" ile güvenlik alt boyutları arasında anlamlı bir ilişkinin olup olmadığını belirlemek için Pearson korelasyon analizi yapılmıştır. Analiz sonucu elde edilen toplu bulgular Tablo 8' de verilmiştir. 


\begin{tabular}{|c|c|c|c|c|c|c|c|c|c|c|}
\hline \multicolumn{11}{|c|}{ Tablo 8. Pearson Korelasyonu } \\
\hline & & 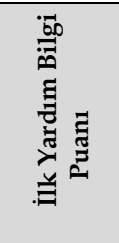 & 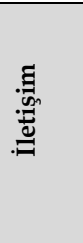 & 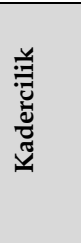 & 茪 & 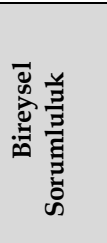 & 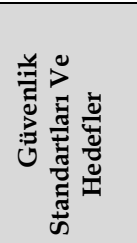 & 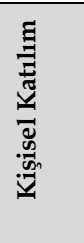 & 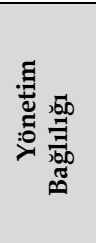 & 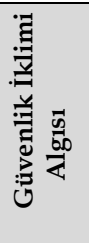 \\
\hline \multirow{4}{*}{$\begin{array}{l}\text { İk Yardım Bilgi } \\
\text { Puanı }\end{array}$} & Pearson Korelasyonu & 1 & $164^{\prime *}$ & $324^{* *}$ & $\begin{array}{r}, 14 \\
7^{*}\end{array}$ & $\begin{array}{r}, 02 \\
2\end{array}$ & $233^{* *}$ & , & $\begin{array}{r}- \\
, 065\end{array}$ & 072 \\
\hline & Sig. (2-tailed) & & & & 01 & ,70 & , 000 & & & \\
\hline & & & 005 & 000 & 1 & 8 & & 874 & 267 & 217 \\
\hline & Kişi Sayısı & $\begin{array}{r}2 \\
97 \\
\end{array}$ & $\begin{array}{r}2 \\
97 \\
\end{array}$ & $\begin{array}{r}2 \\
97 \\
\end{array}$ & 297 & 297 & 297 & $\begin{array}{r}2 \\
97 \\
\end{array}$ & $\begin{array}{r}2 \\
97 \\
\end{array}$ & $\begin{array}{r}2 \\
97 \\
\end{array}$ \\
\hline \multirow{3}{*}{ İletişim } & Pearson Korelasyonu & $164^{\prime *}$ & 1 & $\begin{aligned}- \\
-359^{+*}\end{aligned}$ & $\begin{array}{l}72 \\
1^{* *}\end{array}$ & $\begin{array}{l}30 \\
1^{\text {** }}\end{array}$ & $657^{* *}$ & 025 & $588^{\prime *}$ & $817^{\prime *}$ \\
\hline & Sig. (2-tailed) & 005 & & 000 & $\begin{array}{r}, 00 \\
0\end{array}$ & $\begin{array}{r}, 00 \\
0\end{array}$ & , 000 & 662 & 000 & 000 \\
\hline & Kişi Sayısı & $\begin{array}{r}2 \\
97\end{array}$ & $\begin{array}{r}2 \\
97\end{array}$ & $\begin{array}{r}2 \\
97\end{array}$ & 297 & 297 & 297 & $\begin{array}{r}2 \\
97\end{array}$ & $\begin{array}{r}2 \\
97\end{array}$ & $\begin{array}{r}2 \\
97\end{array}$ \\
\hline \multirow{3}{*}{ Kadercilik } & Pearson Korelasyonu & - & - & 1 & 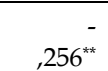 & $\begin{array}{r}- \\
, 065\end{array}$ &,$- 404^{* *}$ & $173^{\prime *}$ & $\begin{array}{r}- \\
076\end{array}$ & $\begin{array}{r}- \\
, 086\end{array}$ \\
\hline & Sig. (2-tailed) & 000 & 000 & & $\begin{array}{r}, 00 \\
0\end{array}$ & $\begin{array}{r}, 26 \\
4\end{array}$ & ,000 & 003 & 192 & $138^{\prime}$ \\
\hline & Kişi Sayısı & $\begin{array}{r}2 \\
97\end{array}$ & $\begin{array}{r}2 \\
97\end{array}$ & $\begin{array}{r}2 \\
97\end{array}$ & 297 & 297 & 297 & $\begin{array}{r}2 \\
97\end{array}$ & $\begin{array}{r}2 \\
97\end{array}$ & $\begin{array}{r}2 \\
97\end{array}$ \\
\hline \multirow{3}{*}{$\begin{array}{l}\text { Güvenlik } \\
\text { Yönetimi }\end{array}$} & Pearson Korelasyonu & $147^{\prime}$ & $721^{\prime *}$ & $\begin{array}{l}- \\
256^{*+}\end{array}$ & 1 & $\begin{array}{l}, 42 \\
2^{* *}\end{array}$ &, $705^{* *}$ & $160^{\prime *}$ & $611^{\prime *}$ & $892^{\prime *}$ \\
\hline & Sig. (2-tailed) & 011 & 000 & 000 & & $\begin{array}{r}, 00 \\
0\end{array}$ & , 000 & 006 & 000 & 000 \\
\hline & Kişi Sayısı & $\begin{array}{r}2 \\
97\end{array}$ & $\begin{array}{r}2 \\
97\end{array}$ & $\begin{array}{r}2 \\
97\end{array}$ & 297 & 297 & 297 & $\begin{array}{r}2 \\
97\end{array}$ & $\begin{array}{r}2 \\
97\end{array}$ & $\begin{array}{r}2 \\
97\end{array}$ \\
\hline \multirow{3}{*}{$\begin{array}{l}\text { Bireysel } \\
\text { Sorumluluk }\end{array}$} & Pearson Korelasyonu & $022^{\prime}$ & $301^{\prime *}$ & $\begin{array}{r}- \\
-065\end{array}$ & $\begin{array}{l}42 \\
2^{*+*}\end{array}$ & 1 & $1,129^{*}$ & $237^{\prime \prime}$ & $178^{\prime *}$ & $465^{* *}$ \\
\hline & Sig. (2-tailed) & 708 & 000 & 264 & $\begin{array}{r}, 00 \\
0\end{array}$ & & ,026 & 000 & 002 & 000 \\
\hline & Kişi Sayısı & $\begin{array}{r}2 \\
97 \\
\end{array}$ & $\begin{array}{r}2 \\
97 \\
\end{array}$ & $\begin{array}{r}2 \\
97 \\
\end{array}$ & 297 & 297 & 297 & $\begin{array}{r}2 \\
97 \\
\end{array}$ & $\begin{array}{r}2 \\
97 \\
\end{array}$ & $\begin{array}{r}2 \\
97 \\
\end{array}$ \\
\hline \multirow[t]{2}{*}{$\begin{array}{l}\text { Güvenlik } \\
\text { Standartları ve } \\
\text { Hedefler }\end{array}$} & $\begin{array}{l}\text { Pearson Korelasyonu } \\
\text { Sig. (2-tailed) }\end{array}$ & $\begin{array}{r}233^{\prime *} \\
000\end{array}$ & $\begin{array}{l}657^{\prime} \\
000\end{array}$ & $\begin{array}{r}-- \\
004^{* *} \\
000\end{array}$ & $\begin{array}{r}, 70 \\
5^{* *} \\
, 00 \\
0\end{array}$ & $\begin{array}{r}, 12 \\
9^{*} \\
, 02 \\
6\end{array}$ & 1 & $\begin{array}{r}074 \\
205\end{array}$ & $\begin{array}{r}554^{\prime *} \\
000\end{array}$ & $\begin{array}{r}740^{\prime *} \\
000\end{array}$ \\
\hline & Kişi Sayısı & $\begin{array}{r}2 \\
97\end{array}$ & $\begin{array}{r}2 \\
97\end{array}$ & $\begin{array}{r}2 \\
97\end{array}$ & 297 & 297 & 297 & $\begin{array}{r}2 \\
97\end{array}$ & $\begin{array}{r}2 \\
97\end{array}$ & $\begin{array}{r}2 \\
97\end{array}$ \\
\hline \multirow{3}{*}{ Kişisel Katılım } & Pearson Korelasyonu & , 009 & $025^{\prime}$ & $173^{\prime \prime *}$ & $\begin{array}{l}16 \\
0^{* *}\end{array}$ & $\begin{array}{l}23 \\
7^{* *}\end{array}$ & 074 & 1 & $078^{\prime}$ & $321^{\prime *}$ \\
\hline & Sig. (2-tailed) & $874^{\prime}$ & 662 & 003 & $\begin{array}{r}, 00 \\
6\end{array}$ & $\begin{array}{r}, 00 \\
0\end{array}$ & ,205 & & 179 & 000 \\
\hline & Kişi Sayısı & $\begin{array}{r}2 \\
97\end{array}$ & $\begin{array}{r}2 \\
97\end{array}$ & $\begin{array}{r}2 \\
97\end{array}$ & 297 & 297 & 297 & $\begin{array}{r}2 \\
97\end{array}$ & $\begin{array}{r}2 \\
97\end{array}$ & $\begin{array}{r}2 \\
97\end{array}$ \\
\hline \multirow{6}{*}{$\begin{array}{l}\text { Güvenlik İklimi } \\
\text { Algısı }\end{array}$} & Pearson Korelasyonu & $\begin{array}{r}- \\
, 065\end{array}$ & $588^{\prime *}$ & $\begin{array}{r}- \\
, 076\end{array}$ & $\begin{array}{l}61 \\
1^{* *}\end{array}$ & $\begin{array}{l}17 \\
8^{*+}\end{array}$ &, $554^{* *}$ & $078^{\prime}$ & 1 & $774^{\prime *}$ \\
\hline & Sig. (2-tailed) & $267^{\prime}$ & 000 & 192 & $\begin{array}{r}, 00 \\
0\end{array}$ & $\begin{array}{r}, 00 \\
2\end{array}$ & ,000 & 179 & & 000 \\
\hline & Kişi Sayısı & $\begin{array}{r}2 \\
97\end{array}$ & $\begin{array}{r}2 \\
97\end{array}$ & $\begin{array}{r}2 \\
97\end{array}$ & 297 & 297 & 297 & $\begin{array}{r}2 \\
97\end{array}$ & $\begin{array}{r}2 \\
97\end{array}$ & $\begin{array}{r}2 \\
97\end{array}$ \\
\hline & Pearson Korelasyonu & 072 & $817^{\prime *}$ & $\begin{array}{r}- \\
, 086\end{array}$ & $\begin{array}{l}, 89 \\
2^{* 4}\end{array}$ & $\begin{array}{l}46 \\
5^{* *}\end{array}$ & ,740* & $321^{\prime *}$ & $774^{\prime *}$ & 1 \\
\hline & Sig. (2-tailed) & $217^{\prime}$ & 000 & 138 & $\begin{array}{r}, 00 \\
0\end{array}$ & $\begin{array}{r}, 00 \\
0\end{array}$ & ,000 & 000 & 000 & \\
\hline & Kişi Sayısı & $\begin{array}{r}2 \\
97\end{array}$ & $\begin{array}{r}2 \\
97\end{array}$ & $\begin{array}{r}2 \\
97\end{array}$ & 297 & 297 & 297 & $\begin{array}{r}2 \\
97\end{array}$ & $\begin{array}{r}2 \\
97\end{array}$ & $\begin{array}{r}2 \\
97\end{array}$ \\
\hline
\end{tabular}




\section{Tartışma}

Sağlıklı ve güvenli bir yaşam tüm toplumların ulaşmak istediği bir hedeftir. Afet veya kazalara karşı alınması gereken akılcı tedbir ve önlemler bu hedefin önündeki en önemli engelleri kaldıracaktır. İnsanlar afetlerle mücadele için afet yönetimi bilimini ortaya koydukları gibi; yaşamlarının üçte birini geçirdikleri çalışma alanlarında sağlık ve güvenliklerini temin için iş sağlığı ve güvenliği bilimini ortaya koymuşlardır (Holmes, Gifford, Triggs, 1998). Her iki bilim dalı da tüm dünyada gelişim aşamasındadır. Araştırmamıza konu olan İSG ve ilk yardım tüm iş sahalarında önem arz etmesine rağmen afet veya kaza risklerinin en yüksek olduğu sanayi ve maden gibi kuruluşlarda daha büyük bir önem kazanmıştır. Büyük sanayi kuruluşlarımızın \%98'i deprem bölgelerinde yer alması, ayrıca kara ve demir yolu ulaşımının bu bölgelerin içinden geçmesi, kimyasal üretim fabrikalarının ve afinerilerin, barajların inşa yerlerinin doğru seçilememesi, kentlerin plansız ve düzensiz bir şekilde yapılaşması doğal afetlerden sonra oluşan ikincil tehlikeler için de önemli bir risk teşkil etmektedir (Kadığlu, 2009). 17 Ağustos 1999 depreminden sonra Kocaeli Sanayi Odası'nın raporlarına göre oda üyesi 1062 işletmeden 345'i hasar görmüştür. Depremden önce üye işletmelerin çalışma kapasiteleri \%70 iken, depremden bir ay sonra ortalama kapasite \%31 olmuştur. Kapasite, depremden 6 ay sonra ortalama \%54'e çımıştır. Üretim ortalama 34 gün durmuştur (Sungur, 2004). Ülkemizde 2013 Nisan ayı itibariyle sanayide istihdam edilenlerin sayısı geçen yılın aynı ayına göre yüzde 5 artarak 5 milyon 30 bin kişiyle tarihi zirvesine ulaşmıştır (milliyet.com, 2015). Ocak 2014 resmi istatistiklerine göre madencilik ve taş ocaklarında çalışan işçi sayısı 190 bin 346'dır (hürriyet.com, 2015). Her gün büyük riskler altında çalışan bu bireylerin İSG ve ilk yardım konularında eğitilmesi iş yerlerinin en büyük önceliği olmalıdır. Bu öncelik yalnızca çalışan bireylerin sağlık ve güvenliğini sağlamakla kalmayacak ekonomik anlamda üretimi etkileyecektir. İşyerlerinde sağlık ve güvenlik açısından büyük tehdit oluşturan tehlikelerin yol açtığı olumsuz sonuçların sadece $\% 2$ 'si önlenemez nitelikte iken, $\% 98^{\prime}$ i önlenebilir niteliktedir. İSG alanında yapılan çalışmaların amacı da, sağlık ve güvenlik tehlikelerinden ve bunların yarattığı risklerden arındırılmış çalışma ortamlarının sağlanmasıdır (Kılkış, Demir , 2012). İş sağlığ1 ve güvenliği yönetim sisteminin (İSGYS) Önemli unsurlarından olan ilk yardımın önemi daha çok kaza yerine ulaşma süresi ve anında bilinçli ilk yardım yapma ile ilgilidir. Kaza sonrası ölümlerin $\% 10$ 'unun ilk beş dakikada, \%50'sinin ilk 30 dakika içinde meydana gelmesi nedeniyle, yapılacak bilinçli ve yeterli ilk yardımla ölümlerin \%38'inin kaza yerinde yapılan ilk yardımla, \%62'sinin ambulans veya helikopterle ulaşan acil yardım hizmetleriyle önlenebileceği saptanmıştır. En etkili ilk yardım ilk 5 dakikada, en bilinçli ilk yardım ise ilk yarım saat içerisinde yapılmaktadır (Yürügen, Durna, 1992). Kretschmer ; ISG ile ilgili standartlar geliştikçe, iş yerlerindeki olası kaza riskleri asgari düzeye inmekte ve çalışanlar için sağlıklı ve güvenli bir çalışma ortamı oluşturulmaktadır. Bu olumlu gelişmeler işveren ve işçiler arasında karşıllklı bir güven iklimi oluşumuna sebebiyet vermektedir (Kretschmer , 2004). Mearns ve ark. ; 2003 yılında yaptıkları çalışmada; işletmelerde bir İSG sorumlusunun ve kişisel olarak İSG faaliyetleri ile ilgilenen üst düzey yöneticilerin bulunması, çalışanlara İSG eğitiminin düzenli verilmesi gibi faktörlerin işyerindeki kaza oranlarında bir düşüş sağlayacağını belirtmişlerdir (Mearns, Whirtaker, Flin, 2003) . Lin ve ark. ; İSG konusunda yapılan araştırmaların birçoğu, iş kazalarının yüksek oranda gerçekleşmesinin öncelikli sebebinin İSG uygulamalarının yetersizliğinden kaynaklandığını göstermektedir (Lin, Mills, 2001). Palassis ; İşletmelerde ISSG sistemini geliştirmenin temel amacı; olası riskleri, yaralanmaları, hastalıkları ve ölümleri minimum düzeye indirerek çalışan tazminatlarının yarattığı maliyetleri ve kayıp zamanı azaltabilmektir. Etkin bir İSG yönetim sistemi ayrıca çalışanların verimliliğini, iş tatminini, moral ve motivasyonunu arttırabilmekte, kanunlara uyumu kolaylaştırmaktadır (Palassis, Schulte, Geraci, 2006). Hale; 2003 yılında güvenlik yönetimi konusunu üretim işletmeleri açısından incelemiş, iyi bir İSG yönetimi için tehlike yaratabilecek durumların önceden tespitine imkan tanıyan bir risk yönetiminin gereğini vurgulamıştır (Hale, 2003). Hermanus ; 19.yüzyılın sonlarında madencilikte İSG risklerinin çok yüksek seviyelerde iken zamanla alınan tedbir ve önlemler Avusturalya, Kanada ve $A B D$ gibi ülkelerde iş sağlığ ve güvenliği önlemlerinde büyük başarılar elde edilmişken Güney Afrika madenlerinde aynı önlemler alındığı söylenmesine rağmen madenlerde beklenen başarı 
düzeyi sağlanamamıştır. Bunun sebebini araştırdığında ise İSG sisteminin tam anlamıla uygulanmadığını büyük eksikliklerinin olduğunu belirlemiştir(Hermanus,2007). Lingard ;Avusturalya inşaat işçilerine 24 haftalık ilk yardım eğitimi uygulamalı olarak verilmiş ve bu eğitimin çalışanların iş sağlığı ve güvenliği davranışlarını ve motivasyonlarını nasıl etkilediğini araştırmıştır. İlk yardım eğitiminin katılımcıların motivasyonunu ve iş sağlı̆̆ı ve güvenliği kapsamında ki davranışlarını geliştirdiğini gözlemlemiştir (Lingard, 2002). A ğır; doktora çalışmasında Ankara Ostim metal iş kolunda çalışan 312 kişi üzerinde yaptığı araştırmada, çırakların \%93,2 sinin daha önce herhangi bir şekilde ilk yardım eğitimi almadığını belirlemiştir. Çırakların \%28,2'si iş kazası geçirmiş\%21,5' i çevresinde geçirilen kazaya şahit olmuştur. Geçirilen kazların \%36,3'ü el parmak kesiği yaralanmasıdır. Çırakların ilk yardım konusunda bilgileri eksiktir müfredat programında bu konuda ders yoktur. Çıraklara verilen ilk yardım eğitimi sonrası bilgi düzeyleri 6,5 puan artış olduğunu gözlemlemiştir (Ağır, 2000) . Bakar ; Ankara mesleki eğitim merkezinde eğitim gören çıraklarla, Ankara ilinde bir lisedeki (Kalaba Lisesi) öğrencilerin ilk yardım bilgi düzeylerini kıyaslamış lise öğrencilerinin ilk yardım bilgi puan ortalamalarının daha yüksek olduğunu belirlemiştir. İlk yardım bilgisi toplumun bütün kesimlerinin ihtiyaç duyduğu bir bilgidir ancak riskli grupların daha fazla ihtiyacı bulunmaktadır. Çıraklık eğitimi alan öğrencilerinin ilk yardım sorularına verilen cevaplarda puanların daha yüksek olması gerekirken tersi bir sonuçla karşılaşılmıştır. Çıraklara verilen ilk yardım eğitiminin yeniden gözden geçirilmesi gerekmektedir (Bakar, 2010). Topçuoğlu ; İş güvenliği bilincinin gelişmesini sağlayan önemli unsurlardan biri çalışanların algılama düzeyidir. Algılama düzeyleri geliştikçe önlem alma, kurallara uyma, teknolojiye uyum sağlama ve eğitimle kazanılan becerileri uygulamada olumlu izlenimler elde edilmektedir (Topcuoğlu, Özdemir, 2007). Özvariş; İlk yardım konusu, toplumun ilk yardım uygulamalarını bilmemesi, şoförler, polisler, ağır ve tehlikeli işlerde çalışanlar, itfaiyeciler gibi değişik risk grupları başta olmak üzere, toplumun tamamını ilgilendirmesi, ölümleri, sakat kalmayı ve işgücü kaybını azaltması nedeniyle önemli bir halk sağlığı sorunudur. İlk yardım uygulamalarını bilen, zamanında ve doğru şekilde uygulayabilen kişilerin sayılarının arttırılması, ülke genelinde ilk yardım gerektiren durumlarda ölüm ve sakatlanmaları azaltacaktır sonucuna ulaşmıştır (Özvariş, 1992). Özaslan; Lojistik sektöründe faaliyet gösteren 40 işletmenin katılımıyla gerçekleştirdiği araştırmada çalışanların güvenlik iklimi algı düzeyleri ile çalıştıkları işletmelerin İSGYS düzeyleri arasında ilişki olduğunu ve işletmelerdeki İGYS düzeyinin çalışanların güvenlik iklimi algısını etkilediğini tespit etmiştir. Ayrıca, çalışanların eğitim düzeylerine ve sahip oldukları unvanlara göre, güvenlik iklimi algılarının farklılaştığını gözlemlemiştir. Korkmaz ; yaptığı çalışmada kimya sanayinde görülen iş kazaları ve meslek hastalıklarının nedenleri tespit edilip işverene, işçiye ve devlete yönelik alınması gereken tedbirler üzerinde durmuştur. İş kazaları ve meslek hastalıklarındaki artışın bir nedeni bulunarak kapasite kullanım oranı görüldüğünden kapasite kullanım oranı ile kimya sanayindeki iş kazaları arasındaki ilişki regresyon analizi ile araştırılmış ve kapasite kullanım oranı ile iş kazası arasında \%10 anlamlılık düzeyinde pozitif yönlü bir ilişki bulunmuştur. Bu nedenle bu sektörde alınacak önlemlerle sadece işçilerin sağllğı ve güvenliği emniyet altına alınmayacak, aynı zamanda geçici ve sürekli iş göremezlikten ya da ölümden kaynaklanan işgünü kayıplarının neden olabileceği ekonomik kayıpların önüne geçilerek verimlilik artışı sağlanacaktır (Korkmaz, 2011).Yıldırım ;Ankara bölgesinde imalat sektöründe faaliyet gösteren küçük ve orta ölçekli işletmelerde genel yönetim yapısı hakkında bilgi edinmeyi amaçlayan bir anket, çalışanların is sağlığı ve güvenliği hakkında neyi ne kadar bildiklerini görmek amacıyla da bir anket olmak üzere her işletme için toplam iki anket uygulaması gerçekleştirilmiştir. Yapılan değerlendirmeler sonucunda Ankara bölgesinde imalat sektöründe faaliyet gösteren 214 işletmede İSG alanında yapılan çalışmalarda çok önemli eksiklikler olduğunu gözlemlemiştir. Bu eksikliklerin giderilebilmesi için çok daha disiplinli ve İSG hakkında çok daha bilgiye dayalı çalışmaların yapılmasının zorunlu olduğu sonucuna varmıştır (Yıldırım, 2011). Eker; 2013 yüksek lisans çalışmasında Ülkemiz ölümlü iş kazalarında Avrupa'da birinci, dünyada üçüncü sırada yer almaktadır. 1946'dan 2011 yılına kadar "iş kazaları" sonucu ölen işçi sayısı 59 bin 300'e ulaşmış durumdadır. Her yıl ortalama 1072 işçi hayatını kaybetmektedir. 155 ve 161 sayılı Uluslararası 
Çalışma Örgütü (ILO) sözleşmeleri 2004 yılında kabul edildiğinden bugüne iş kazası sayısı 75 bin civarında seyretmektedir. Meslek hastalıkları sayısı ise ortalama 500 civarındadır. Bu çalışmada bir işletmede yeni çıkan İş Sağlığı ve Güvenliği Kanunu kullanılarak risk değerlendirmesinin yapılması ve uygun değerleme metodunun seçilerek işletmede çalışan işçilerin güvenli bir ortamda yüksek moral ve motivasyon da çalışmaları sağlanmak istenmiştir. Sağlanan bu motivasyon artışı ile şirketin daha verimli üretim yapması amaçlanmıştır (Tomris,2013). Korkmaz ve Avsallı ; Ülkemizde 6331 Sayılı İş Sağlığı ve Güvenliği Yasası'nın kabul edilmesiyle çalışanlar ve iş dünyası açısından önemli bir dönem başlamış oldu. 6331 sayılı kanun, iş sağlığı ve güvenliği bakımından önemli düzenlemeler getirmekte, iş sağlığı ve güvenliğinde "tazmin edici" yaklaşım yerine daha çok "önleyici" bir yaklaşım sergilemektedir. Böylece iş kazaları ve meslek hastalıklarının sonuçlarıyla mücadele etmenin zorluğu ve maliyeti karşısında bu kaza ve hastalıklar ortaya çıkmadan önlemeyi, kaynağında yok etmeyi hedef alan çağdaş standartlarda bir düzen kurgulamaktadır. İş sağlığı ve güvenliği konusunda işverenlerin mutlak anlamda sorumluluklarını açıkça düzenleyen kanun, ayrıca, işyerlerinde ve ulusal düzeyde iş sağlığı ve güvenliği konusunda işçiler ile işverenler arasında etkin diyalog mekanizmaları da getirerek ülkemizin en önemli sorunlarından birisi olan iş kazalarının ve meslek hastalıklarının sayısının azaltılmasında tarafların rollerini ve sorumluluklarını arttırmaktadır. Devletin de, küçük işletmelerin (1-9 işçi çalıştıran işletmeler) iş sağlığı ve güvenliği maliyetlerine katılması da uygulamanın yaygınlaştırılması bakımından büyük önem taşımaktadır (Korkmaz, Avşallı, 2012) .

Çalışmamızda ise afet veya kaza risklerinin yüksek olduğu sanayi ve maden kuruluşlarında çalışan bireylerin iş sağlığı ve güvenliği algı kültürü ve yine kendileri için büyük önem arz eden ilk yardım bilgi düzeylerinin belirlenmesi ile bunlar arasındaki ilişkilerin saptanması hedeflenmiştir. Araştırma Gümüşhane ilindeki Gümüşhane Organize Sanayi Bölgesi, Koza Altın İşletmeleri A.Ş. Gümüşhane Şubesi, Gümüştaş Madencilik Ve Ticaret A.Ş. Gümüşhane Şubesi çalışanlarına yönelik literatür taramaları sonucunda hazırlanan anket 297 kişiye uygulanmıştır. Çalışanların iş yerlerindeki iş sağlığı ve güvenliği iklimi algısını belirlemek için anketörlere 49 adet soru sorulmuştur. Bu sorulara istatistiksel olarak ortalaması 3,54 kararsızım cevabı alınmıştır.

$>$ İş sağlı̆̆ı ve güvenliği algısı ölçümünde alt boyut olan "iletişim" algısının ölçümü için anketörlere 9 adet soru sorulmuştur. Bu sorulara istatistiksel olarak ortalaması 3,77 kararsızım cevabı alınmıştır.

> İş sağlığı ve güvenliği algısı ölçümünde alt boyut olan "kadercilik" algısının ölçümü için anketörlere 4 adet soru sorulmuştur. Bu sorulara istatistiksel olarak ortalaması 2,70 katılmıyorum cevabi alınmıştır.

> İş sağlığı ve güvenliği algısı ölçümünde alt boyut olan "güvenlik yönetimi" algısının ölçümü için anketörlere 11 adet soru sorulmuştur. Bu sorulara istatistiksel olarak ortalaması 3,74 kararsızım cevabi alınmıştır.

> İş sağlığı ve güvenliği algısı ölçümünde alt boyut olan "bireysel sorumluluk" ölçümü için anketörlere 4 adet soru sorulmuştur. Bu sorulara istatistiksel olarak ortalaması 4,13 katılıyorum cevabı alınmıştır.

> İş sağlığı ve güvenliği algısı ölçümünde alt boyut olan "güvenlik standartları ve hedefler" algısının ölçümü için anketörlere 5 adet soru sorulmuştur. Bu sorulara istatistiksel olarak ortalaması 3,72 kararsızım cevabı alınmıştır.

$>$ İş sağlığı ve güvenliği algısı ölçümünde alt boyut olan "kişisel katılım” algısının ölçümü için anketörlere 5 adet soru sorulmuştur. Bu sorulara istatistiksel olarak ortalaması 3,31 kararsızım cevabı alınmıştır.

> İş sağllğ̆ ve güvenliği algısı ölçümünde alt boyut olan “yönetim bağl1lı̆̆ı" algısının ölçümü için anketörlere 5 adet soru sorulmuştur. Bu sorulara istatistiksel olarak ortalaması 3,26 kararsızım cevabi alınmıştır.

$>$ Ayrıca çalışanların ilk yardım bilgi düzeylerini ölçmek için literatür doğrultusunda çalışanların çoğunlukla maruz kalabileceği ilk yardım gerektiren durumlar dikkate alınarak 25 soruluk anket formu hazırlanmıştır. Doğru/Yanlış/Bilmiyorum şeklinde hazırlanan ankette 
puanlama yapılmıştır. Tüm katılımcıların ilk yardım bilgisi puan ortalaması ise 68,47 (100 puan üzerinden) olarak belirlenmiştir.

> Katılımcıların cinsiyeti ile güvenlik iklimi ölçümünün alt boyutu olan "kişisel katılım" algısı arasında anlamlı bir farklılık vardır. Kadınların çalışma ortamlarında kişisel katılımlarının daha fazla olduğu gözlemlenmiştir. Cinsiyetle diğer alt gruplar arasında anlamlı bir farklılık yoktur.

> Katılımcıların eğitim durumları ile güvenlik iklimi ölçümünün alt boyutları olan "iletişim", "kadercilik", "güvenlik standartları ve hedefler" ayrıca "ilk yardım bilgi puanı" arasında anlamlı bir farklılık bulunmuştur. Bu sonuçlara göre eğitim düzeyi arttıkça "iletişim”, "güvenlik standartları ve hedefler" ve "ilk yardım bilgi puanı" artarken kadercilik algısı ise azalmaktadır. Eğitim düzeyi ile diğer alt boyutlar arasında anlamlı bir farklılık yoktur.

> Ankete katılan çalışanların medeni durumları ile güvenlik iklimi algısı ve alt boyutları olan "iletişim", "kadercilik", "güvenlik yönetimi", "güvenlik standartları ve hedefler" arasında anlamlı bir farklılık bulunmuştur. Bu sonuçlara göre evlilerde güvenlik iklimi algısı, "iletişim", "kadercilik", "güvenlik yönetimi", "güvenlik standartları ve hedefler" düzeyi daha yüksek iken "kadercilik" algısının ise bekarlarda daha yüksek olduğu gözlemlenmiştir. Katılımcıların medeni durumları ile diğer alt boyutlar arasında anlamlı bir farklılık yoktur.

$>$ Katılımcıların yaşları ile güvenlik iklimi algısının alt boyutları olan "kadercilik" ve "güvenlik standartları ve hedefler", algıları arasında anlamlı bir farklılık bulunmuştur. Bu sonuçlara göre çalışanların yaşları arttıkça bu algıların arttığı gözlenirken. En genç katılımcılarda "kadercilik" algısın yüksek olduğu da saptanmıştır. Katılımcıların yaşları ile diğer alt boyutlar arasında anlamlı bir farklilik yoktur.

> Ankete katılan çalışanların aylık gelirleri ile güvenlik iklimi algısı ve alt boyutları olan "iletişim", "kadercilik", "güvenlik yönetimi" , "güvenlik standartları ve hedefler", "yönetim bağlılığı" algıları arasında anlamlı bir farklılık bulunmuştur. Bu sonuçlara göre çalışanların aylık gelirleri arttıkça güvenlik iklimi ve alt boyutları olan "iletişim", "güvenlik yönetimi", "güvenlik standartları ve hedefler", "yönetim bağlılı̆̆ı" algılarının arttığı, kadercilik algısının ise azaldığ1 gözlemlenmiştir. En yüksek gelire sahip katılımcıların yönetim bağlılığında bir miktar azalma olduğu da saptanmıştır. Katılımcıların aylık gelirleri ile ile diğer alt gruplar arasında anlamlı bir farklilik yoktur.

$>$ Ankete katılan çalışanların işletme türleri (maden ve sanayi) ile güvenlik iklimi algısı ve alt boyutları olan "iletişim", "kadercilik", "bireysel sorumluluk", "güvenlik standartları ve hedefler" ve ilk yardım bilgi puanı arasında anlamlı bir farklılık olduğu gözlemlenmiştir. Maden işletmelerinde çalışanların güvenlik iklimi algısı ve alt boyutları olan "iletişim, "güvenlik standartları ve hedefler" ile ilk yardım bilgi puanı yüksek ortalamaya sahip iken sanayi birimlerinde ise kadercilik ve Ankete katılan çalışanların mesleklerindeki konumları ile güvenlik iklimi algısı ve alt boyutları olan "iletişim", "kadercilik", "güvenlik yönetimi", "güvenlik standartları ve hedefler" ve ilk yardım bilgi puanı arasında anlamlı bir farklılık olduğu gözlemlenmiştir. Mesleklerindeki konumları teknisyen, uzman ve yönetici olan çalışanların güvenlik iklimi algısı, iletişim, güvenlik yönetimi, güvenlik standartları ve hedefler ve ilk yardım bilgi puanı ortalaması daha yüksek iken, mesleklerindeki konumları işçi, usta ve çırak olan çalışanların kadercilik algısının yüksek olduğu gözlemlenmiştir.

> Ankete katılan çalışanların ilk yardım eğitimi alıp almama durumları ile güvenlik iklimi algısının alt boyutları olan "iletişim", "kadercilik", "güvenlik yönetimi" , "güvenlik standartları ve hedefler" ve ilk yardım bilgi puanı arasında anlamlı bir farklılık olduğu gözlemlenmiştir. Bu sonuçlara göre çalışanlardan ilk yardım eğitimi alanların "iletişim”, " güvenlik yönetimi”, " güvenlik standartları ve hedefler" ve ilk yardım bilgi puanı ortalamaları daha yüksek çıkarken, "kadercilik" algısı ilk yardım eğitimi almayan katılımcılarda daha yüksek çıkmıştır.

$>$ Ankete katılan çalışanların ilk yardım eğitimi alma istekleri ile güvenlik iklimi algısının alt boyutları olan "iletişim”, "kadercilik" ve ilk yardım bilgi puanı arasında anlamlı bir farklılık olduğu gözlemlenmiştir. Bu sonuçlara göre çalışanlardan ilk yardım eğitimi almak isteyenlerde "iletişim" 
algısı ve ilk yardın bilgi puan ortalaması daha yüksek iken ilk yardım eğitimi almak istemeyenlerde ise "kadercilik" algısının daha yüksek olduğu saptanmıştır.

> Katılımcıların iş kazası geçirip geçirmeme durumları ile güvenlik iklimi algısının alt boyutları olan "kadercilik", "bireysel sorumluluk", "güvenlik standartları ve hedefler" ve ilk yardım bilgi puanı arasında anlamlı bir farklılık olduğu gözlemlenmiştir. Bu sonuçlara göre iş kazası geçiren katılımcıların "kadercilik" ve "bireysel sorumluluk" algıları daha yüksek çıkarken iş kazası geçirmeyen katılımcılarda ise "güvenlik standartları ve hedefler" algısı ile ilk yardım bilgi puan ortalamasının daha yüksek olduğu saptanmıştır.

Ankete katılan çalışanların iş sağlığı ve güvenliği eğitimi alıp almama durumları ile güvenlik iklimi algısının alt boyutları olan "iletişim", "kadercilik", "güvenlik yönetimi", "bireysel sorumluluk", "güvenlik standartları ve hedefler" ve ilk yardım bilgi puanı arasında anlamlı bir farklılık olduğu gözlemlenmiştir. Bu sonuçlara göre çalışanlardan iş sağlığı ve güvenliği eğitimi alanlarda "iletişim", "güvenlik yönetimi", "güvenlik standartları ve hedefler" ve ilk yardım bilgi puan ortalaması daha yüksek iken bu eğitimi almayanlarda ise "kadercilik" ve "bireysel sorumluluk" algılarını daha yüksek çıktığı saptanmıştır.

$>$ Ankete katılan çalışanların iş sağlığı ve güvenliği eğitimi alma istekleri ile güvenlik iklimi algısının alt boyutları olan "iletişim" ve "güvenlik yönetimi" algıları arasında anlamlı bir farklılık olduğu gözlemlenmiştir.

Bu sonuçlara göre çalışanlardan iş sağlı̆̆ı ve güvenliği eğitimi almak isteyenlerde "iletişim" ve "güvenlik yönetimi" algılarının daha yüksek olduğu saptanmıştır.

\section{Sonuç ve Değerlendirme}

$\mathrm{Bu}$ çalışma ile sonuç olarak, Gümüşhane ili Sanayi ve Maden çalışanlarının demografik bilgileriyle güvenlik iklimi algısının yedi alt boyutu (İletişim, Kadercilik, Güvenlik Yönetimi , Bireysel sorumluluk, Güvenlik Standartları Ve Hedefler, Kişisel Katılım, Yönetim Bağlılığı) arasındaki ilişkilere bakıldığında; İletişim algısının; evlilerde, eğitim durumu yüksek olanlarda, geliri ve mesleki konumu yüksek olanlarda, büyük işletmelerde çalışanlarda, İSG ve ilk yardım eğitimi alanlarda yüksek ve anlamlı farklılık olduğu, Kadercilik algısının; bekar ve eğitim seviyesi az olanlarda, en genç ve en yaşlı gruplarda, aylık geliri ile mesleki konum seviyesi düşük olanlarda, büyük işletmelerde çalışanlarda ayrıca İSG ve İlk yardım eğitimi almayan ve iş kazası geçirenlerde yüksek ve anlamlı farklılık olduğu ,Güvenlik yönetimi algısının; evlilerde, geliri ve mesleki konumu yüksek olanlarda, İSG ve İlk yardım eğitimi alanlarda yüksek ve anlamlı farklılık olduğu, Bireysel Sorumluluk algısının; sanayi çalışanlarda, iş kazası geçirenlerde, İSG eğitimi almayanlarda daha yüksek ve anlamlı farklılık gösterdiği, Güvenlik Standartları ve Hedefler algısının; evlilerde, eğitim düzeyi yüksek olanlarda, yaşı büyük olanlarda, aylık ve mesleki konumu yüksek olanlarda ve iş kazası geçirmeyenlerde ayrıca İSG ve İlk yardım eğitimi alanlarda daha yüksek ve anlamlı farklılık olduğu, Kişisel Katılım algısının , kadınlarda kişisel katılım algısının daha fazla ve anlamlı farklılık olduğu, Yönetim Bağlılığı algısı, aylık geliri yüksek olanlarla daha fazla ve anlamlı farklılık olduğu belirlenmiştir. İlk yardım Bilgi Seviyesinin, eğitim düzeyi yüksek olanlarda, iş kazası geçirmeyen madencilerde, mesleki konumu yüksek olanlarda ayrıca İSG ve ilk yardım eğitimi alanlarda daha yüksek ve anlamlı farklılıklar olduğu gözlemlenmiştir. İlk yardım bilgi seviyesi ile güvenlik iklimi alt boyutlarından "iletişim", "güvenlik yönetimi güvenlik standartları" arasında zayıf pozitif yönde ilişki var iken kadercilikle negatif yönde zayıf bir ilişki olduğu belirlenmiştir. İnsanlar, yaşamlarının büyük bir kısmını geçirdikleri iş yerlerinde sağlıklı ve güvenli bir şekilde çalışmayı istemektedirler. Çalışanların İSG ve bu kapsamda ki ilk yardım eğitimi ile bilinçlendirilmesi, çalışma ortamlarındaki güvenli ve sağlıklı iklim algılarını olumlu yönde etkileyecektir. Kendilerine değer verildiğini anlayan çalışanların yönetime olan bağlılıkları ve güvenleri artacak, maden ve sanayi gibi çalışma koşullarının çok ağır olduğu iş yerlerinde dahi verimli çalışmayı destekleyecektir. Bu durum iş kayıplarını önleyip üretimi olumlu yönde etkileyecek ve ekonomik anlamda da ülkemize kazançlar sağlayacaktır. Bu olumlu neticelerin elde edilebilmesi için tüm çalışanlara İSG eğitimi ve ilk yardım bilgisi düzenli aralıklarla verilmelidir. 


\section{Kaynakça}

A ğır, A. (2000), Metal İş Kolunda Çalışan Çırakların İlk Yardım Bilgi Düzeylerinin Tespiti ve Geliştirilmesi, Doktora Tezi, Gazi Üniversitesi Fen Bilimleri Enstitüsü, s. 23.

Bakar, C. (2010), Mesleki Eğitim Merkezinde ve Düz Lisede Öğrenim Gören Öğrencilerin İlkyardım Bilgi Düzeylerinin Karşılaştırılması, Türk Tabibler Birliği Mesleki Sağlık ve Güvenlik Dergisi, s.41-47.

Hale, AR. (2003), Safety Management in Production, Human Factors and Ergonomics in Manufacturing, 13-3, s. 186-190.

Hermanus, M.A.(2007), Occupational Health And Safety İn Mining Status, New Developments, And Concerns, The Journal of The Southern African Institute of Mining and Metallurgy, Volume 101, s.331-338.

Holmes, N. Gifford, SM., Triggs , TJ. (1998), Meanings Of Risk Control In Occupational Health And Safety Among Employers And Employees, Safety Science, s. 141-154.

Kadıoğlu, M. (2009), Sanayi ve İş Yerleri İçin Afet Acil Yardım Planlama Rehberi, TC. İstanbul Valiliği, s.15.

Kaya, M. (2013), Türk Kamu Yönetiminde Gönüllülük ve Afet Yönetimi, Yüksek Lisans Tezi, Atılım Üniversitesi Sosyal Bilimler Enstitüsü, Ankara, s. 36.

Kılkış, İ., Demir, S. (2012), İşverenin İş Sağlığı ve Güvenliği Eğitimi Verme Yükümlülüğü Üzerine Bir İnceleme, Çalışma İlişkileri Dergisi, 3.1, s.23-47.

Korkmaz, A., Avsallı, H. (2012) , Çalışma Hayatında Yeni Bir Dönem: 6331 Sayılı İş Sağlı̆̆1 ve Güvenliği Yasası, SDU Faculty Of Arts And Sciences Journal Of Social Sciences , Sayı:26, s. 153-167.

Korkmaz, O. (2011), Türkiye Kimya Sanayinde İşçi Sağlığı ve İş Güvenliği, Zonguldak Karaelmas Üniversitesi, Sosyal Bilimler Dergisi, Cilt 7, Sayı 14, 2011.

Kretschmer, H. (2004), Türkiye' de İş Sağlığı ve Güvenliği İyileştirilmesi Projesi Başlatıldı, İSG, İş Sağhlğı ve Güvenliği Dergisi, Sayı 17, Yıl 4, Ocak-Şubat 2004 s. 4.

Lin, J., Mills, A. (2001), Measuring the Occupational Health and Safety Performance of Construction Companies in Australia, Facilities, Vol. XIX, No: 3/4,s. 131.

Lingard, H. (2002), The Effect Of First Aid Training On Australian Construction Workers' Occupational Health And Safety Knowledge And Motivation To Avoid Work Related Injury Or Illness, Construction Management And Economics, Volume 20 İssue 3.

Martin ,J. (2007), The Meaning Of The 21st Century: A Vital Blueprint For Ensuring Our Future, Oxford Üniversity, Riverhead Books.

Mearns, K., Whitaker, SM., Flin, R.(2003), Safety Climate, Safety Management Practice and Safety Performance in Offshore Environments, Safety Science, 41, s. 643.

Özvariş, Ş. B. (1992) , Hacettepe Halk Sağlı̆̆1 Vakfı İlk Yardım Eğitim Becerileri Hizmet İçi Eğitim Programına İlişkin Katılımcı Görüşleri, Yüksek Lisans Tezi, Hacettepe Üniversitesi , Sosyal Bilimler Enstitüsü, s. 5-6.

Palassis, J., Schulte, Pa., Geraci, CL. (2006), A New American Management Systems Standard in Occupational Safety and Health, Journal of Chemical Health \& Safety, s. 21.

Sungur, Z. (2004), Doğal Afet Kaynaklı Risk Olgusunun Petrokimya ve Akrilik Kimya Sanayi Sektörlerinde Sosyolojik Açıdan Değerlendirilmesi Kocaeli ve Yalova Uygulamaları, Anadolu Üniversitesi Sosyal Bilimler Enstitüsü, Çalışma Ekonomisi ve Endüstri İlişkisi Anabilim Dal,, Doktora Tezi, Eskişehir, s.14-16.

Tomris ,E. (2013) ,İş Sağlığı ve Güvenliği Kapsamında Risk Analizi ve Metal Sektöründe Bir Uygulama, Yüksek Lisans Tezi , Haliç Üniversitesi, İstanbul.

Topçuoğlu, H., Özdemir, Ş. (2007), İş Sağlı̆̆1 ve Güvenliğinde Davranış Değişikliği Yaratma Süreci, Mühendis ve Makine, C. 48, Sayı: 567, s. 11.

Yıldırım, V. (2011), Küçük ve Orta Ölçekli İşletmelerde İş Sağlıgı ve Güvenligi: Bir Alan Arastırması, Yüksek Lisans Tezi, Gazi Üniversitesi Fen Bilimler Enstitüsü.

Yurdigül, A. (2014), Olumsuz Olayların Televizyon Ana Haber Bültenlerinde Sunumu: Soma Faciası Üzerine Bir İnceleme Çalışması, Gümüşhane Üniversitesi İletişim Fakültesi Elektronik Dergisi 2.4. 
Yürügen, B., Durna, Z. (1992), Afetlerde Hemşirelik Bakımı ve İlk Yardım, T.C. Anadolu Üniversitesi Yayınları No :569, Eskişehir.

http://www.Milliyet.Com.Tr/Sanayi-İstihdami-Rekor-Kirdi

Ekonomi/Detay/1737238/Default.Htm (16.7.2015)

http://www.Hurriyet.Com.Tr/Ekonomi/27671917.Asp (19.7.2015)

\section{Extended Abstract}

\section{Aim and Scope}

After many painful experiences, our country has issued new laws aiming to eliminate or minimize risks against all kinds of disasters and accidents, and especially in recent years, it has entered the implementation phase with the constantly updated regulations. One of these important measures is occupational health and safety law, which aims to prevent technological or humaninduced disasters and accidents. This research is a small example that can shed light on the position of the concept of occupational health and safety, which is of great importance for our country, at the level of working individuals by measuring the safety climate perceptions and first aid knowledge levels of the personnel working in industrial and mining organizations.

\section{Methods}

A questionnaire has been prepared by us by carrying out the necessary literature studies. In the first part of the questionnaire form, information about the purpose and scope of the research was given, and in the second part, demographic features were included (13 questions). In the next section, there are 25 questions formed as true / false / do not know for determining first aid knowledge level, and in the last section, there are 49 questions using a 5-point Likert type scale aiming to measure the safety climate of employees within the scope of occupational health and safety. The respondents were asked to respond to each statement in accordance with their own views. One of the non-random sampling methods among the employees of the Gümüshane Branch was applied to a sample determined by the convenience sampling method. Research was applied in Gümüşhane Organized Industrial Zone in Gümüşhane province, Koza Altın İşletmeleri A.Ş. Gümüşhane Branch, Gümüştaş Madencilik ve Ticaret A.Ş. This research was conducted by the Gümüşhane Organized Industrial Zone, Koza Altın İşletmeleri A.Ş. Gümüşhane Branch, Gümüştaş Madencilik ve Ticaret A.Ş. Gümüşhane Branch employees. 340 employees were reached in total. In the entry of the filled questionnaires, it was observed that the data of 43 questionnaires were incomplete and inaccurate and were excluded from the analysis, and the number of subjects included in the analysis was 297. For demographic analysis in the questionnaire form, analyzes such as frequency, percentage, arithmetic average are made in the form of tables and tables. One-Sample Kolmogorov-Smirnov Test was applied to determine whether the findings conformed to the normal distribution. In the analysis of the research; Nonparametric tests where the significance is from $p$ $<0.05$ (Table 1) and does not show normal distribution were applied; Kruskal-Wallis, Mann-Whitney U test was used.

\section{Findings}

9 questions were asked to the subjects in order to measure the perception of "communication", which is a sub-dimension in the measurement of occupational health and safety perception. The statistical average of 3.77 indecisive answers to these questions was obtained. 4 questions were asked to the subjects in order to measure the perception of "fatalism", which is a sub-dimension of occupational health and safety perception. A statistically average of 2.70 "Disagree" answers were obtained for these questions. 11 questions were asked to the subjects to measure the perception of "safety management", which is a sub-dimension of occupational health and safety perception. The statistical average of 3.74 indecisive answers to these questions was obtained. For the measurement of "individual responsibility", which is a sub-dimension in the perception of occupational health and safety, 4 questions were asked to the subjects. A statistically average of 4.13 answers to these questions was obtained. In order to measure the perception of "safety standards and targets", which 
is a sub-dimension in the measurement of occupational health and safety perception, 5 questions were asked to the subjects. The statistical average of 3.72 indecisive answers to these questions was obtained. 5 questions were asked to the subjects in order to measure the perception of "personal participation", which is a sub-dimension in the measurement of occupational health and safety perception. The statistical average of 3.31 undecided answers to these questions was obtained. In order to measure the perception of "management commitment", which is a sub-dimension in the perception of occupational health and safety, 5 questions were asked to the subjects. The statistical average of 3.26 indecisive answers to these questions was obtained. In addition, in order to measure the first aid knowledge level of the employees, a 25-question questionnaire was prepared in line with the literature, taking into account the situations requiring first aid that the employees may be exposed to. Scoring was made in the questionnaire prepared as True / False / Don't Know. First aid knowledge point average of all participants was determined as 68.47 (out of 100 points).

\section{Conclusion}

People want to work in a healthy and safe way in their workplaces where they spend most of their lives. Raising the awareness of employees through OHS and first aid training in this context will positively affect their perception of safe and healthy climate in their work environment. Employees who understand that they are valued will increase their loyalty and confidence in management, and support efficient work even in workplaces such as mining and industry where working conditions are very severe. This will prevent job losses, affect production positively and provide economic gains to our country. In order to achieve these positive results, all employees should be given OHS training and first aid information at regular intervals. 